The University of San Francisco

USF Scholarship: a digital repository @ Gleeson Library |

Geschke Center

Communication Studies

College of Arts and Sciences

2009

\title{
Transcribing Refugees: The Entextualization of Asylum Seekers' Hearings in a Transidiomatic Environment
}

Marco Jacquemet

University of San Francisco, mjacquemet@usfca.edu

Follow this and additional works at: http://repository.usfca.edu/coms

Part of the International and Intercultural Communication Commons

\section{Recommended Citation}

JACQUEMET, M. (2009). Transcribing refugees: the entextualization of asylum seekers' hearings in a transidiomatic environment. Text \& Talk, 29(5), 525-546

This Article is brought to you for free and open access by the College of Arts and Sciences at USF Scholarship: a digital repository @ Gleeson Library | Geschke Center. It has been accepted for inclusion in Communication Studies by an authorized administrator of USF Scholarship: a digital repository @ Gleeson Library | Geschke Center. For more information, please contact repository@usfca.edu. 


\section{Transcribing refugees: the entextualization of asylum seekers' hearings in a transidiomatic environment}

MARCO JACQUEMET

\section{Abstract}

This article explores the link between asylum seekers' verbal performances and their transidiomatic entextualization by documenting the procedure through which asylum seekers' claims are examined by judicial authorities and translated into a public record. Every year thousands of displaced people seek the protection of various European states by filing political asylum claims which are examined by national commissions. In their depositions, asylum seekers are interviewed by immigration officials for approximately an hour. After this interview they are presented with a judgment: a short text that summarizes their story and spells out the commission's decision on the case. The claim of this article is that these commissions are structurally unaware of the need to address the transidiomatic nature of the hearing. In this light, the entextualization of the asylum seeker's verbal performance becomes much more than the process of rendering a single instance of talk into text, detachable from its local context; rather, it reveals how public officials, faced with the intrinsic alterity of the asylum seekers, rely on commonsensical, but at times inappropriate, knowledge of social, cultural, and linguistic values to construct, process, and eventually determine the validity of each claim. As a result, this procedure is fraught with unexamined assumptions about language, national identity, and communicative competence, leading to egregious violations of the asylum seekers' human rights.

Keywords: refugees; institutional talk; transcription; transidiomatic practices; European Community; interpreters.

Language diversity has been historically under the influence of two contrasting myths: in the name of Babel, humankind has been punished with the confusion of the languages. In the name of Pentecost, the plurality of languages is on the 
contrary understood as a gift to humankind. Political power, in both its aristocratic and democratic modes, has always strived to force us to abandon the Pentecostal swarm of plural tongues for a single language, before Babel. (Roland Barthes, inaugural lecture, Collège de France, 7 January 1977)

\section{Introduction}

While judicial systems around the world vary, the regulation of justice everywhere revolves around the construction of a public space where words are exchanged and carefully recorded-whether in memory or through various media. The construction of a record, i.e., the entextualization of public verbal performances in institutional settings, is thus the representation of the world in moral terms acceptable to the linguistic ideology and textual routines of the dominant classes (Bauman and Briggs 1992; Jacquemet 1996; Jaffe in this issue; Bucholtz 2000). This is true not only in the regulation of conflicts but also in the processing by government agencies of all legal claims requiring face-to-face interaction.

In classic studies of bureaucratic encounters (in the long descent line from Weber 1947 [1915] to Habermas 1987 [1981]), the nature of faceto-face interactions has been understood solely in terms of power or class asymmetry between the bureaucrat and the petitioner, thus taking for granted that the language of these encounters was a commonly shared and negotiable feature of the interlocutors' common nationality. As such, the potentially problematic communicative nature of the interaction remained poorly analyzed and understood. It was only when scholars interested in intercultural communication started investigating governmentality and institutional talk that the communicative performances of "nonstandard" speakers came to be viewed as problematic and was duly placed at the center of the investigation. Still, the majority of these studies occupied themselves with minority populations, from migrant settled communities to ethnic minorities (Gumperz 1982; Merry 1990; Rampton 1995; Conley and O'Barr 1998; Heller and Martin-Jones 2000; Haviland 2003). In so doing, they established a paradigm for the study of the interface between majority and minority languages which assumed this interface to be fairly stable and consistent over time (cf. Rosenthal in this issue).

This understanding of intercultural communication in institutional talk as based on a majority/minority dichotomy is now coming apart. The last two decades have been characterized by the progressive globalization of communicative practices and social formations resulting from the increasing mobility of people, languages, and texts (Giddens 1990; Appadurai 1996; Jameson and Miyoshi 1998; Tomlinson 1999; Nederveen Pieterse 
2003). Sophisticated technologies for rapid human mobility and electronic global communication, such as high-capacity airplanes, television cable lines and networks, fixed and mobile telephony, and the Internet, are producing communicative environments where multiple languages and multiple channels of interaction are simultaneously evoked by transnational speakers no longer anchored in clearly identifiable national languages (De Swaan 2001; Danet and Herring 2007; Pennycook 2007; Blommaert 2009; Park in this issue). Elsewhere I use the term transidiomatic practice to describe the communicative practices of groups of people, no longer territorially defined, that communicate using an array of both face-to-face and long-distance media and in so doing produce and reproduce the social hierarchies and power asymmetries we came to associate with postcolonial, late industrial class relations (Jacquemet 2005a). Instead of relying on linguistic-focused concepts such as "multilingualism" or "multimodal communication" to describe this phenomenon, I introduced this new concept to capture the novelty of communicative environments in which different languages and communicative codes are simultaneously present in a range of communicative channels, both local and distant. ${ }^{1}$

Transidiomatic practices are the result of the co-presence of digital media and multilingual interaction exercised by deterritorialized/reterritorialized speakers. They operate in contexts heavily structured by the social indexicalities and semiotic codes characterizing late modernity. Anyone present in transnational environments whose interactions are produced by both physical and digital means and found in both present and distant settings is engaged in transidiomatic practices.

Moreover, transidiomatic practices are no longer solely restricted to areas of colonial and postcolonial contact but flow thorough the multiple channels of electronic communication and global transportation over the entire world, from contact zones, borderlands, and diasporic nets of relationships to the most remote and seemingly self-contained areas of the globe. These communicative resources are activated by people needing to operate in multiple, co-present, and overlapping communicative frames. The language they use to communicate depends on the contextual nature of their multi-sited interactions, but it is necessarily mixed, translated, or, in Hannerz's (1996) words, "creolized."

Given the nature of economic globalization, many contemporary work environments, from the offices of international organizations to airport lounges, from international call centers to the board meetings of multinational companies, can be classified as transidiomatic. In addition, a great number of social settings, from living rooms to hospital operating rooms to political meetings, experience a translocal multilingualism interacting 
with the electronic technologies of contemporary communication. The world is now full of settings where speakers use a mixture of languages in interacting with friends and coworkers; read English and other "global" languages on their computer screens; watch local, regional, or global broadcasts; and listen to pop music in various languages. Much of the time, they do so simultaneously.

One of the consequences of this cultural globalization is the emergence of a transnational concern in the work of national governments and international institutions, especially those charged with regulating the flow of deterritorialized people - in particular, migrants and refugees. Faced with the influx of foreigners seeking refuge and a better life, nation-states respond by setting up their own transidiomatic environments, creating institutional settings able to handle these deterritorialized speakers and their multiple languages (through the use of interpreters), their technologically mediated needs (by providing access to Web sites containing information useful to their cases), and their multimodal communication (relying on case workers, cultural mediators, and social advocates).

Despite such efforts, even in these settings the interview process remains a site where transidiomatic practices come into conflict with national language ideologies. As a result, state bureaucrats impose national norms and forms on people barely able to understand the nation's local language, let alone the process of conducting in-depth interviews, writing reports, and producing a record that is institutionally required in order to grant them access to local resources (Eades and Arends 2004; Pollabauer 2004; Maryns and Blommaert 2001; Blommaert 2009).

Nation states rely on national ideologies to make sense of asylum seekers' claims and to determine their credibility. However, as a result of the interferences created by the two opposing modalities - transidiomatic versus national - the performances of asylum seekers are routinely framed as "difficult" and "problematic" and, as a result, are handled with suspicion, thus seriously affecting their credibility.

Moreover, the interview is only the first step in the process of granting asylum. All interviews need to enter the legal record, and it is on the basis of this entextualization that asylum is granted or, in case of denial, that an appeal can be launched. In this light, the entextualization of the asylum seeker's verbal performance becomes much more than the process of rendering a single instance of talk into text, detachable from its local context (Bauman and Briggs 1990; Briggs and Bauman 1992; Silverstein and Urban 1996). Rather, it reveals how public officials, faced with the intrinsic alterity of asylum seekers and the tension between transidiomatic and national codes, rely on commonsensical, but at times inappropriate, local knowledge to produce the public record. 
Most confusions in the record can be traced to officials' construction of a text based on their cultural assumptions, which are rooted in dominant national values. As Bucholtz (2000) points out, all transcripts take sides, promoting certain interpretations and interests at the expenses of others, linking the transcript to the context in which it is intended to be read (see also Vigouroux in this issue). As such, the hearing itself becomes structured around the need to produce a written record compatible with the linguistic ideology and textual routines of the dominant classes. In this logic, public officials routinely reduce the semantic ambiguities and multiple voicing proper to any transidiomatic environment to a univocal statement to be summarized in the record.

Finally, we must take into consideration the distortion of the message in the transfer from speech to written statements, especially in light of translation concerns (Berk-Seligson 1990; Pollabauer 2004; Jacquemet 2000, 2005b; Good 2007). Interpreters in asylum hearings frequently assume roles that are shaped by the perceived expectations of the officials in charge, which lead them to modify statements, volunteer explanations, and at times antagonize the asylum seeker, with serious repercussions on the production of the record. In this article, I examine how three different European nations-Italy, the United Kingdom, and Belgium-handle asylum procedures, focusing in particular on the role played by the entextualization of the asylum deposition in the process of determining the asylum seeker's credibility. ${ }^{2}$ After describing the asylum hearing, I explore how the complex nature of communication in a transidiomatic environment can lead to inaccurate transcriptions of the applicant's performance in the hearing. These inaccuracies are traced to three basic features of entextualization described above: (i) the construction of a text based on dominant cultural assumptions (as scripted into the hearing); (ii) the reduction of semantic ambiguities and multiple voicing to a univocal statement; and (iii) the distortion of the message in the transfer from speech to written statement.

\section{The asylum hearing}

Seeking asylum for fear of persecution is an inviolable human right, recognized by the United Nations Geneva Convention of 1951. In the Geneva Convention it is stated that a "refugee" (i.e., a person who has fled his/her country on the basis of a well-founded fear of persecution for reason of race, religion, nationality, or membership in a particular social group or political affiliation) has the right to seek refuge in any country that is a signatory of the convention. The host country, in turn, has the 
right to determine the validity of the applicant's claim through questioning and examination of supporting evidence before granting asylum.

The asylum hearing is one of the technologies of power set up by international and national agencies for managing mass displacements of people. Together with the refugee camp (see Malkki 1995), the hearing process establishes an ordered, replicable, and consistent operation that depends on smooth interactional routines to achieve its goal of surveillance, discipline, and control. In this way, the registration process may be considered a discourse practice. As we know from Foucault, discourse practices do not necessarily seek to depict the world: rather, they dictate the world by mobilizing tactics of social indexicality and strategies of social inequality advantageous to the dominant group(s) in charge of institutional decision making.

Interviewing applicants for refugee status is, then, the crucial moment in the determination of a case. These interviews are usually conducted by government or UN personnel, at times assisted by an interpreter. The goal of the hearing is to determine the credibility of the asylum seeker. According to documents of the United Nations High Commission for Refugees (UNHCR), credibility should be assessed by examining the applicant's testimony both for internal consistency (the coherence of the statement) and for external validity (the statement's agreement with known facts). Interviewers are also instructed to "consider the fluency of the testimony (that is, the incidence of hesitation) as well as its clarity and detail" (United Nations High Commission for Refugees 1995: 42).

At the end of the deposition, the interviewer prepares a written report, stating the decision or recommendation regarding the asylum claim. In this document, the interviewer usually includes a basic description of the claimant, an outline of the evidence and arguments presented in support of the claim, a brief assessment of the evidence presented, and a concise statement of the recommended decision. In particular, the UNHCR suggests that in preparing the assessment and conclusions of the report, the interviewer should highlight the key points of the claim and summarize those aspects that argue for and against recognition of refugee status. The UNHCR goes on to acknowledge that "determining refugee status is a professionally demanding and onerous task requiring considerable knowledge, skills, and good judgment" (United Nations High Commission for Refugees 1995: 45).

Despite the centrality of writing in asylum hearings, UNHCR literature gives very little attention to the entextualization of these proceedings. Yet the process of structuring talk-including the deposition of the asylum seeker-into institutionally sanctioned text involves a dynamic of entextualization that not only is based on power asymmetries (as Blommaert 
2001 has conclusively argued; see also Bucholtz in this issue) but also operates within a transidiomatic environment where different cultural assumptions and ways of speaking clash.

Both the UNHCR and local governments recognize the need to provide technical support for the asylum seeker's deposition in the form of an interpreter, but this support is often insufficient. For instance, in an encounter examined by Katrijn Maryns (2005: 220) that is reproduced as Example (1) below, a Belgian official (O in the transcript) interviewed an asylum seeker (AS) who stated that he was from Sierra Leone; both an interpreter (I) and legal counsel (Law) were present to assist AS. The hearing came to a halt when the interpreter realized that the asylum seeker was barely proficient in Krio, the Sierra Leone creole usually spoken as a lingua franca by refugees from that region:

(1) (Maryns 2005: 220)

O: can you speak in your own language

Krio hen to explain

AS: yeah

(...)

Law: est-ce qu'il ne sait pas expliquer ça

doesn't he know how to explain

dans la langue maternelle à vous

this in your mother tongue?

le Créole?

the creole?

I: c'est Créole

It's Krio

O: $\quad$ mais oui mais-

yes, but, but-

I: $\quad$ il ne sait pas le Krio même

he doesn't even know Krio

il ne parle pas bien

he doesn't speak it well

je ne comprends pas

I can't understand him

(...)

[some lines omitted, then AS switches to English]

O: $\quad$ I would prefer that you speak

in your mother language Krio

AS: I speak Krio little

because we-

we speak a little bit words 
I: $\quad$ I want to ask you

what language do you speak?

AS: we speak the Njala language

O: hold on please, yeah you are not really speaking Krio then tell me what is Njala language

AS: Njala people speak Njala

O: ok

AS: we come, but to do something withto do something for people we speak Krio to talk to people say business, we do Krio

This transcript provides a clear example of the intrinsic difficulties of transidiomatic communication in an institutional setting: English was a non-native language for all the participants, who spoke it at various skill levels; French was either the first or second language for some (the official, the legal counsel, and the interpreter), while the interpreter was clearly the only fluent speaker of Krio, and the asylum seeker was the only Njala speaker. It is important to note that the official's insistence to have the asylum seeker speak in his "mother tongue" can be traced back to a linguistic ideology of origins, so that the official can detect the claimants' home country by attending to their ways of speaking and in particular to their phonetic production (on the problematic link between language analysis and determination of asylum, see Jacquemet 2000; Eades 2005). On the other hand, the asylum seeker's explanation of his linguistic background focuses precisely on its transidiomatic nature ("to do something for people, we speak Krio; say business, we do Krio") — but this is not really acknowledged either by the interpreter ("he doesn't even know Krio") or by the official ("you are not really speaking Krio").

Out of this jumble of conflicting understandings, linguistic ideologies, and interrogation routines, the processing agency had to produce a report evaluating the credibility of the applicant, a procedure that becomes highly problematic in the likely absence of any corroborating evidence for the asylum seeker's testimony.

\section{The institutional interplay between entextualization and cultural assumptions}

In all institutional encounters, state agents and applicants have different roles and degrees of interactional power, but in addition they have different goals. In the process of creating a record, the bureaucrat acts based 
on two ideological concerns: how an official text should be structured, and on what moral and cultural values this text should be based. The bureaucrat brings to the entextualization process particular cultural assumptions of what the text should look like, what textual elements should be highlighted, and what statements are deemed not relevant enough to make the cut in the transfer from the verbal performance to the text. This is the normal state of affairs in interactions between citizens and their state bureaucracy. What happens, then, when these institutional interactions cross national lines and take place in a transidiomatic environment?

One of the most basic findings in the study of intercultural communication points to the divergence in expectations and interpretations among the people involved in such exchanges. People with different cultural backgrounds bring to intercultural interactions a particular set of expectations about how the action will unfold (expectations most likely not shared by their interlocutors) and use these expectations to interpret the behavior of others. In addition, given the different institutional roles of the participants, they frequently have different, and at times antagonistic, goals and desired outcomes. Most intercultural breakdowns can be attributed to these cross-purposes (see Gumperz 1982; Holliday et al. 2004; Scollon and Scollon 1995).

In the power-saturated environment of asylum hearings, we do not witness a clash between equally matched expectations and interpretations as much as the demolition by the cultural assumptions of the dominant party (i.e., state bureaucrats) of any alternative vision of the performance under way. Moreover, these cultural assumptions are themselves governed by a strong, elaborate, and enforced set of interviewers' guidelines, provided by the national authorities. These cultural assumptions, in other words, are canalized through a set of institutional regimentations that provide for the stability and cross-case comparability of the entextualization processes. In this light, power asymmetry and cultural differences are thus present both in the development of the highly regulated exchange and in the assessment (and final report) of the claim.

In the case of asylum hearings in Italy, dominant cultural assumptions about the economic reasons for the majority of undocumented migrants are scripted to probe asylum seekers about their work in the home country and their desire to work in Italy. While these questions are not among the list of standardized questions that form the basis of the final report, they are nevertheless asked during asylum hearings and at times utilized to justify denials (ICS 2005: 65). ${ }^{3}$

The question about work in Italy is particularly problematic, since it pits the asylum seeker's desire not to be perceived as a "social parasite" 
against the bureaucrat's suspicion of the true motives for the applicant's presence in Italy. In the testimony of an asylum seeker gathered by the Consorzio Italiano Solidarietà (Italian Consortium for Solidarity or ICS, an Italian nongovernmental organization working with refugees), these differences are clearly at play: "When they asked me if I wanted to work in Italy, I immediately answered yes. I thought it was the best thing to say, so that they would have thought that once I was recognized as a refugee I would take care of myself, without having to rely on the Italian state." In the report on this asylum seeker's case, the hearing commission writes: "The denial is based on the fact that the applicant stated that he left his country to seek better living conditions and better chances to find work" (ICS 2005: 70; my translation).

Moreover, in a widely shared pattern of state mistrust of asylum seekers, Italian officials have also assessed nationality claims by asking asylum seekers to sing or recite the anthem of the nation they report themselves to be fleeing, or to describe the colors and patterns of the national flag. This preoccupation with national symbols is more a reflection of Italian assumptions about national unity and citizenship than an appropriate test of applicants' claims, since many asylum seekers come from areas where displaying nationality (and its symbols) is not a common practice. The failure of applicants to demonstrate knowledge of national symbols is nonetheless used by Italian authorities as another reason for denying claims.

In the Belgian cases analyzed by Katrijn Maryns (2005), cultural assumptions also take center stage in both the interview and the entextualization of the hearing; the assumptions in these cases concern the importance and relevance of personal names and toponyms. In her lengthy analysis of a particular political asylum hearing involving a man from Cameroon seeking asylum after having escaped from prison (2005: 14-160), Maryns describes how, in the questioning of the asylum seeker, the government official focuses on the identity of the people that appear in his narration of his prison time and eventual escape. In recalling his time in prison, the asylum seeker mentions the death of a fellow inmate:

(2) (Maryns 2005: 57)

O: how long were you in the- inside the cell

AS: I've been there for ... from January ... January urm urm seven 2000 till the- till around July July that I was sick so much... one body one boy died...

O: July 2000

AS: hu- yeah. July 2000 
As a result of his illness and his fellow inmate's death, the asylum seeker was sent to a hospital where he enlisted the help of a boy to escape:

(3) (Maryns 2005: 76)

AS: I was sent to the hospital and a nurse warned me to run away then one day a boy come and I told him to go to my business, to Pete for my driving license, and he came back with a loaf of bread with the driving license in it

O: what's the name of the boy?

AS: I don't know his proper name

O: ok

Later on the narrator was arrested again; in Example (4) he describes the arrival in jail of an important inmate, the brother of a local police officer: ${ }^{4}$

(4) (Maryns 2005: 69)

AS: the the they CAUGHT ... a brother of one commissioner, family member of one commissioner...

O: yes

AS: they CAUGHT him and put him in the cell so the man discovered that they catched caughted his brother

O: so this commissionary was also caught

AS: hen?

$\mathrm{O}$ : he was also in the cell

AS: uh uh.. no

no, the brother, the brother of the commissioner

caught was caught and put in the cell that I was we we were there

$\mathrm{O}$ : in you in your cell. in the same cell

AS: there he was tortured. he was tortured (xx) usthey never knew that he was the brother of a commissioner

O: yes

In Example (2), we see the official's concern with timelines (which leads him to ignore the traumatic event of the death of the asylum seeker's fellow inmate in the Cameroonian prison). In Example (3), the asylum seeker's long account of his time in the hospital and his escape is largely ignored as the official focuses only on getting the name of a main character in the story. Example (4) shows considerable confusion in communication between the official and the applicant. 
These three moments were entextualized in the official report with a strong emphasis on the applicant's inability to provide proper names for the individuals mentioned in his narrative. The parenthetical metacommentary provides the institutional view of the asylum seeker's testimony:

The applicant spent a lot of time in prison, was tortured, didn't see his family. Until somebody died (the applicant does not know his name)... One day a boy came to give food to a patient. Before that, a nurse had warned him already that he should escape but he said that he did not have the strength to do so. When that boy came (the applicant does not know his name, $N W 4060 B$ ) he told him to go to his workplace.... The applicant was handcuffed, the legs also, he was there until March 2001, then a brother of a police officer was brought in. The very same day the commissioner came with a higher official (the applicant does not know names of any of them). (translated from Dutch by Maryns 2005: 152-153; my italics)

On the basis of this entextualization, the asylum claim was denied because of the asylum seeker's lack of credibility. In the final verdict the commission cites, among other factors, the applicant's lack of knowledge of proper names:

It is little acceptable that the applicant does not know the name of the boy who died and who was also locked up in the same cell as the applicant, or the name of the boy who played such a role in his escape. It is also striking that the applicant does not know the name of the brother of the police officer, the police commissioner himself and the higher officer who came to release the brother.... From what it precedes it becomes clear that the application is deceptive. (Maryns 2005: 161)

This judgment fails to take into account that knowledge of personal names is highly variable across cultures: some cultures prefer kin terms in referring to people (Hanks 2003), others discourage sharing personal names with strangers (for instance, the Tuareg studied by Youssouf et al. 1976), or prefer nicknames or generic names (Jacquemet 1992). CalameGriaule (1986), in her ethnography of the Dogon, a population living in Burkina Faso and Mali, points out the complex patronymic system in place in this culture, where different names (from personal to taboo) are used in different contexts and situations. The commission's judgment also fails to acknowledge Western bureaucrats' taken-for-granted habit of judging testimony credible based on the applicant's ability to provide proper (i.e., verifiable and objective) identification. In the above case, we can see this habit not only in the official's unwillingness to explicitly ask for the names of the people mentioned (Example [3] is the only passage in which the official clearly asks the applicant about the identity of a character in the story), but also, later on, in the entextualization of the story, where the absence of names becomes a sign of the unreliability of the ap- 
plicant's deposition. Moreover, the parenthetical comment ("the applicant does not know (his) name") literally breaks up the flow of the recorded narrative, making the deposition appear broken and incoherent, and according to the language ideology that links fluency and truthfulness, unreliable. This insertion of evaluative comments thus seems to have a significant role in entextualization.

Here we can see how the two modalities of the asylum process can conflict: whereas during the interview the official did not seek the proper name of the characters in the story, in his role as entextualizer the importance of providing proper forms of identification comes to center stage, and the asylum seeker's failure to volunteer the names becomes evidence of his unreliability as a bona fide refugee.

In the entextualization of the deposition, bureaucrats become keenly aware of the need to provide objective reasons for their decision, and in so doing they highlight certain elements of the deposition, such as proper names, which in the sequential organization of the exchange itself have not been the focus of talk. This practice points to a potentially dangerous dynamic within bureaucratic entextualization: the criteria for relevance during talk-in-interaction may be significantly different from those utilized in reporting on the talk - thus leading to potentially egregious distortions in the record itself.

\section{The reduction of semantic ambiguities and multiple voicing to a univocal statement}

A second area of concern in the institutional production of a written record is the erasure of potential ambiguity from the record itself. Even in monolingual settings, the polysemic nature of language is not particularly suited to the necessarily binary logic ("guilty/not guilty," "granted/ denied," "admitted/expelled") of the speech acts performed in the institutional production of the legal record. We could view all appellate proceedings (from the first appeals court to the highest court) as attempts to resolve the ambiguities of the record through a never-ending process of semiotic reinterpretation.

In asylum hearings, semantic ambiguities, already present in any monolingual setting, become increasingly difficult to handle due to the transidiomatic nature of the deposition. In many instances, the hearing is not conducted in the asylum seeker's first language, necessitating the presence of an interpreter. If an interpreter is present, he or she may know a different variety of the language from that spoken by the applicant. The transfer of ambiguous statements from one language to another 
is a well-known problem (especially in translation and interpreting studies; see for example Venuti 2000). What is less well understood is the institutional impact of such a transfer.

In an expansion of Susan Berg-Seligson's (1990) model for examining interpreting in the courtroom, Moira Inghilleri (2003) focuses on the reduction of polysemic statements to monosemic statements in the transfer from the source language to the official language in asylum hearings in the United Kingdom. In her analysis of a Central American asylum seeker, she discusses how the semantic ambiguities of the Spanish word fracaso were lost in the transfer from the asylum seeker's deposition in Spanish to the interpretation in English. In the regional variety of Spanish spoken in Central America, this term is used in two radically different contexts: it can refer to economic or financial failure as well as to physical harm and structural body failure. In this case, the ambiguity became a crucial element in determining the motives of the applicant's escape from his Central American home. The applicant had explained that he fled because of fear of fracaso. The interpreter translated this as fear of economic failure, and the applicant's statement was recorded as such. In a series of successive judgments, bureaucrats of the Home Office relied upon this entextualization to deny the asylum application on the grounds that the applicant was an "economic migrant" rather than a "political refugee."

A similar situation occurred in another case discussed by Inghilleri (pers. comm.), in which an asylum seeker from Turkish Kurdistan was interviewed about the day he was arrested by the Turkish secret police. In his testimony, he declared that the police arrived at mealtime, using the Kurdish word chêsht, which can refer either to a generic meal or to the main meal of the day, usually eaten in the evening. In this case, the interpreter elected to translate the word with the English 'dinner' (possibly being led astray by the verb shêw 'to dine', see Hakim and Gautier 1993). This translation was interpreted by the authorities as referring to the evening meal. Later on in the deposition, the asylum seeker described how he had been beaten and left bloodied and handcuffed in the courtyard "for the entire afternoon." When this apparent temporal anomaly between the time of the arrest and the beating was challenged by the examining official, the interpreter raised the possibility of a linguistic confusion, while not admitting to having made a mistake (most likely for fear of being judged incompetent, which could have led the Home Office to seek another interpreter). The interpreter then sought to clarify the answer by proposing that the official again ask the question about when the police had arrived. The official, however, rejected this suggestion on the grounds that a witness cannot answer the same question twice. Thus the temporal 
contradiction stemming from the first answer remained on the record and became supporting evidence for denying the application.

In both of these cases, the need to produce an official written record exerts further pressure to generate a univocal statement, devoid of semantic ambiguities. Because of the institutional, interpreting, and time constraints of the hearing, these ambiguities are buried in the production of the record, turning all instances of interpretation into a hermeneutic enterprise for the record reader.

\section{The distortion of the record}

In all transidiomatic environments, different ways of speaking may give rise to different interpretations of the intended illocutionary force. In a groundbreaking analysis, John Gumperz (1982) demonstrated how differing use of certain contextualization cues (in particular intonation, stress, and tempo) can lead to serious misunderstanding among speakers of different varieties of the same language.

This risk of communicative breakdown increases in institutional environments saturated by power asymmetries. In these environments, petitioners who lack the particular communicative competences sanctioned by bureaucracies or who cannot get bureaucrats to listen to them may find that their verbal style is not only at odds with that of the bureaucrats investigating their case but also in serious danger of not being properly recorded.

In reviewing recent cases of entextualized distortions in asylum hearings as reported by researchers and advocacy groups for asylum seekers, I found frequent occurrences of speech-to-text mistakes specifically in relation to the practice of naming.

Naming comes into play in two different scenarios:

1. Self-identification. Because most asylum seekers arrive in refugee processing centers without proper forms of identification, they are routinely asked to state their name.

2. Evidence. As we have already seen, during the hearings, officials seek out names in the process of determining the credibility of a claim.

In the Italian situation, most asylum seekers arrive on small overcrowded boats launched from the Southern shores of the Mediterranean Sea. In most cases, they carry a cell phone and a minimal amount of baggage or none at all, and they lack identity papers, because these either have been destroyed or have become unreadable during the water-soaked trip. As a result, one of the first acts applicants are asked to perform in 
front of Italian immigration officials is to provide their name. This act, however, is far from unproblematic. Italian officials unfamiliar with foreign names, lacking proper interpreting support, and rushed to process as expeditiously as possible a boatful of people routinely make mistakes in transcribing the names of asylum seekers. These failed transcriptions will later have serious consequences for the applicants.

For instance, an Italian nongovernmental organization working on behalf of refugees reported the case of Mr. Boukhari, a refugee from Southern Morocco. Mr. Boukhari did not understand Italian, but he knew some French words. The official processing his case in the Identification Center in Lampedusa wrote down his name incorrectly in the transcription of the hearing. To compound the mistake, Mr. Boukhari, unfamiliar with the Roman alphabet, did not realize the spelling was wrong when he signed the report. He was admitted to the country on humanitarian grounds and was granted a one-year stay permit. Once settled, he applied for a permanent work visa. When the Italian Immigration Office reviewed his application, however, they discovered the difference between the name recorded in his first interview in the Identification Center and the name he was using in his application for a work permit. He was accused of having entered the country under a false name and his one-year stay permit was revoked (Rovelli 2006: 151).

In a similar case, Mr. Adesida, a Nigerian refugee, was admitted to Italy in 2003 and given a one-year work permit. When the permit was about to expire, he went to the Immigration Office to renew it, where he was arrested on the grounds that he had filed his request under a false name. It turned out that the report of his original interview had omitted one of his four personal names. Not only was his renewal denied, but he was arrested and confined in Milan's detention center for undocumented migrants and then sent back to Nigeria (ICS 2005: 56).

If the above cases point to the Kafkaesque rigidity of bureaucracy, another case studied by Maryns (2005: 280-291) highlights the transidiomatic difficulty in the entextualization of a hearing when both speakers not only use a lingua franca with which they are both uncomfortable (English in this case) but also are driven by radically different motivations: the asylum seeker wanted to tell her story, but the official sought elements in the story that could be recorded and later checked:

(5) (Maryns 2005: 280-291)

O: I gonna start with the story so what happened to you in Sudan that you have to leave the country [30 lines omitted] 
AS: don't- when they are fighting we run

$\mathrm{O}$ : you just run away uhum

and what happened to you

run away... so where to

AS: one man... one man carry me, help me

O: Karimi

AS: yeah

O: it was a man or a woman?

AS: man

Unfamiliarity with different ways of speaking English, combined with the official's need for concrete evidence in the form of a name, produced a classic communicative breakdown: "carry me" became the man "Karimi." The fact that the claimant seems to confirm the official's suggested name is due to a common pattern I observed during asylum hearings, whereby the claimant's preferred second pair part to the official's leading questions was always in agreement with the first pair part. This catastrophic miscommunication would later be transcribed in the official report as follows:

(...) I left Juba because of fight. Everyone I knew ran away. I could not see anyone anymore and I escaped as well. A man named Karimi helped me. He brought me somewhere and told me that I was safe. (Maryns 2005: 291)

The final case of distortion of the record in asylum hearings concerns the speed and tempo of the utterance. The material comes from another of the cases analyzed by Maryns (2005), one we already encountered above in Examples (2) through (4), in which the asylum seeker described the death of a fellow prison inmate. In Example (6), it is the fast tempo and emphatic stress of the asylum seeker, again combined with the official's need to entextualize referential content, that produces the miscommunication:

(6) (Maryns 2005: 42)

AS: they cut the door down I see a gun

I go like this (puts arms in the air)

O: yes

AS: as I tell $\mathrm{xxx}$ had so many of $\mathrm{xxx}$

O: u hum

AS: then I discover that I'm REALLY shaking

$\mathrm{O}$ : military people?

AS: yeah yeah that is the gendarm the gendarm and the gendarmes the gendarmes

$\mathrm{O}: \quad$ one moment please hen (writes down) 
they broke down the door you saw this gun

you saw it were- it were military people

AS: gendarmes gendarmes

O: u hum ... ok ... what happened then

AS: when they sent me inside a vehicle

at my business place

they call it a secret gendarmerie car

The asylum seeker's statement "I'm really (shaking)" was understood by the official as "military (people)." Here again, the official's version was quickly seconded by the claimant, leading to the following written statement:

... The door got broken down. I saw military people and was caught under fire, overmastered and beaten, my wife also.... I was taken away and pushed inside a car of the secret gendarmerie. (Maryns 2005: 85)

Later on, the claimant's credibility was challenged on the basis of this apparent contradiction between a common raid conducted by the military and a much more complex operation carried out by the secret corps of the gendarmerie, or military police.

This misunderstanding is typical of transidiomatic environments where English becomes the de facto lingua franca of the proceedings. However, due to different levels of ability and/or different ways of speaking, this supposedly common communicative ground is in reality a very shaky ground. Often, neither the applicants nor the officials can claim "ownership" over the language they are using, but the communicative practices of the officials are the ones privileged in the resulting entextualization. In this case, different ways of speaking and unequal access to entextualization led to a record of the hearing which clearly did not represent the applicant's intention, leading to potential violations of the asylum seeker's human rights.

\section{Conclusions}

The entextualization of asylum hearings is one of the most powerful structuring instruments used by nation states to grant noncitizens refuge and access to valuable resources. However, the linguistic ideology of the nation state still frames the habits and policies of immigration and asylum agencies. In particular, most assessments of asylum claims either are based on ethno-national criteria or assume a taken-for-granted knowledge of "the language of the land." For instance, as Blommaert (2003: 
616) points out, national identity and ethnolinguistic identity often do not match, and ethnolinguistic identities must be understood as generated by discursive practices resulting from the impact of "spatial trajectories" on language acquisition. Instead of looking at asylum cases from a spatialresidential and sedentary perspective (in Blommaert's words, displaying "modernist reactions to postmodern realities"), we need to make immigration agencies aware of the fact that asylum seekers' communicative practices and cultural knowledge, rather than pointing to a clear origin, index an itinerary across communities, which can be traced through their transidiomatic mixtures and blends of accents, lexemes, speech styles, and genres.

The danger of relying on cultural and textual assumptions based on a monolingual ideology in entextualizing refugees' speech is clearly visible in the texts produced during the hearings. Decisions to grant or deny refugee status were based primarily on texts informed by agency officials' folk views of language and culture and demonstrated scant intercultural competence. The texts presented above are a poor representation of the transidiomatic performances of an asylum hearing, performances which emerge out of the deployment of linguistic and discursive practices that may have no connection to a single, clearly demarcated cultural and communicative environment.

How can nation states and international agencies take into account the structural, cultural, and linguistic instability of these hearings in judging asylum seekers' credibility? Instead of looking at the credibility of a deposition through a lens that takes communicative practices in a transidiomatic environment to be unproblematic, immigration agencies need to become aware not only of the ways in which speech is shaped by the transidiomatic nature of the hearings but also of the fact that the record reveals asymmetrical access to the entextualization of different performances, where officials possess all the textual resources to impose their version of events as the legitimate one. Therefore, state officials need to pay close attention to their entextualization of these transidiomatic interactions, for it is the texts, not the hearings themselves, that provide the basis for decisions to grant or deny asylum.

Most immigration and asylum agencies are still under the influence of the Babel myth, or the ideological desire to maintain linguistic singularity, believing that only in singularity can communication be rendered unproblematic. In this article, as instructed by Barthes in the epigraph that opens this article, I have taken the side of Pentecost: of the xenoglossic need to investigate texts produced in a context of linguistic confusion. The study of entextualization must focus on examining communicative practices based on disorderly recombinations and language mixings that 
are often overlooked because they do not belong clearly to any linguistic system. While the issue of the bivalency of language has been already discussed by various scholars (Rampton 1995, 1998; Woolard 1999; Pennycook 2007), it is now time to extend it to the study of institutional entextualization. In other words, it is time to conceptualize the entextualization of xenoglossic becoming, transidiomatic mixing, and communicative recombinations.

\section{Notes}

1. The root word idiomatic in transidiomatic does not mean "an expression that has a meaning contrary to the usual meaning of the words (such as 'it's raining cats and dogs')" (Oxford English Dictionary, s.v. idiom), but, more generically, "the usual way in which the words of a particular language are joined together to express thought" (Oxford English Dictionary, s.v. idiomatic).

2. The selection of the somewhat eclectic data presented here is the consequence of a search for communicative patterns of asylum hearing which could be considered prototypical and common of the process itself in Western bureaucracies. Italian data come from ethnographic fieldwork conducted in summer 2006, supported by a grant from the Human Rights Working Group at the University of San Francisco. The British data come from Inghilleri (2003, 2005, pers. comm.), and the Belgian data come from Maryns (2005). (When this article was initially conceived, two important references, Good [2007] and Bohmer and Shuman [2008] were not available yet.)

3. The basic questions, in order, are: determination of personal identity and biographical information, itinerary, applicant's ethnic religious or political affiliation, detention history, motivations for leaving the country, possible consequences in case of deportation, request of additional information the applicant wants to be known (ICS 2005: 61-67).

4. CAPS in the transcript indicate prosodical extra-prominence.

\section{References}

Appadurai, A. 1996. Modernity at large. Minneapolis: Minnesota University Press.

Bauman, R. \& C. Briggs. 1990. Poetics and performance as critical perspectives on language and social life. Annual Review of Anthropology 19. 59-88.

Bauman, R. \& C. Briggs. 1992. Genre, intertextuality, and social power. Journal of Linguistic Anthropology 2(2). 131-172.

Berk-Seligson, S. 1990. The bilingual courtroom: Court interpreters in the judicial process. Chicago: University of Chicago Press.

Blommaert, J. 2001. Investigating narrative inequality: African asylum seekers' stories in Belgium. Discourse \& Society 12(4). 413-449.

Blommaert, J. 2003. Commentary: A sociolinguistics of globalization. Journal of Sociolinguistics 7. 607-623.

Blommaert, J. 2009. Language, asylum, and the national order. Current Anthropology 50(4). 415-441. 
Bohmer, C. \& A. Shuman. 2008. Rejecting refugees: Political asylum in the 21st century. London: Routledge

Bucholtz, M. 2000. The politics of transcription. Journal of Pragmatics 32. 1439-1465.

Calame-Griaule, G. 1986. Words and the Dogon world. Philadelphia: Institute for the Study of Human Issues.

Conley, J. \& W. O’Barr. 1998. Just words: Law, language, and power. Chicago: Chicago University Press.

Danet, B. \& S. Herring (eds.). 2007. The multilingual Internet. Oxford: Oxford University Press.

De Swaan, A. 2001. Words of the world. Cambridge: Polity.

Eades, D. 2005. Applied linguistics and language analysis in asylum seeker cases. Applied Linguistics 26(4). 503-526.

Eades, D. \& J. Arends (eds.). 2004. [Special issue on language analysis in asylum hearings]. International Journal of Speech, Language and the Law 11(2).

Giddens, A. 1990. The consequences of modernity. Stanford, CA: Stanford University Press.

Good, A. 2007. Anthropology and expertise in the asylum courts. London: Routledge.

Gumperz, J. 1982. Discourse strategies. Cambridge: Cambridge University Press.

Habermas, J. 1987 [1981]. The theory of communicative action, T. McCarthy (trans.). Oxford: Blackwell.

Hakim, H \& G. Gautier. 1993. Dictionnaire Français-Kurde. Paris: Klincksieck.

Hanks, W. 2003. Referring to persons in Mayan conversation. Berkeley: Department of Anthropology unpublished manuscript, University of California.

Hannerz, U. 1996. Transnational connection: Culture, people, places. London: Routledge.

Haviland, J. 2003. Ideologies of language: Reflections on language and US law. American Anthropologist 105. 764-774.

Heller, M. \& M. Martin-Jones. 2000. Voices of authority. Norwood, NJ: Ablex.

Holliday, A., M. Hyde \& J. Kullman. 2004. Intercultural communication. London: Routledge.

ICS-Consorzio Italiano Solidarietà. 2005. La protezione negata. Milan: Feltrinelli.

Inghilleri, M. 2003. Habitus, field and discourse: Interpreting as a socially-situated activity. Target 15(2). 243-268.

Inghilleri, M. 2005. Mediating zones of uncertainty: Interpreter agency, the interpreting habitus, and political asylum adjudication. Translator 11(1). 69-85.

Jacquemet, M. 1992. Namechasers. American Ethnologist 19(4). 90-105.

Jacquemet, M. 1996. Credibility in court. Cambridge: Cambridge University Press.

Jacquemet, M. 2000. Translating refugees: Kosovar interpreters as linguistic detectives. Connect 1(1). 61-69.

Jacquemet, M. 2005a. Transidiomatic practices: Language and power in the age of globalization. Language and Communication 25. 257-277.

Jacquemet, M. 2005b. The registration interview: Restricting refugees' narrative performances. In M. Baynham \& A. De Fina (eds.), Dislocations/relocations: Narratives of displacement, 197-220. Manchester: St. Jerome Publishing.

Jameson, F. \& M. Miyoshi (eds.). 1998. The cultures of globalization. Durham, NC: Duke University Press.

Malkki, L. 1995. Refugees and exiles. Annual Review of Anthropology 24. 495-523.

Maryns, K. 2005. The asylum speaker: Language in the Belgian asylum procedure. Manchester: St. Jerome Publishing.

Maryns, K. \& J. Blommaert. 2001. Stylistic and thematic shifting as a narrative resource: Assessing asylum seekers' repertoires. Multilingua 20(1). 61-84. 
Merry, S. E. 1990. Getting justice and getting even: Legal consciousness among working class Americans. Chicago: University of Chicago Press.

Nederveen Pieterse, J. 2003. Globalization and culture. Lanham, MD: Rowman and Littlefield.

Pennycook, A. 2007. Global Englishes and transcultural flows. London: Routledge.

Pollabauer, S. 2004. Interpreting in asylum hearings: Issues of role, responsibility and power. Interpreting 6(2). 143-180.

Rampton, B. 1995. Crossing: Language and ethnicity among adolescents. London: Longman.

Rampton, B. 1998. Speech community. In J. Verschueren, J.-O. Ostman \& J. Blommaert (eds.), Handbook of pragmatics, 1-34. Amsterdam: Benjamins.

Rovelli, M. 2006. Lager Italiani. Milan: Biblioteca Universale Rizzoli.

Scollon, R. \& S. Wong Scollon. 1995. Intercultural communication. Oxford: Blackwell.

Silverstein, M. \& G. Urban (eds.). 1996. Natural histories of discourse. Chicago: University of Chicago Press.

Tomlinson, J. 1999. Globalization and culture. Chicago: University of Chicago Press

United Nations High Commission for Refugees. 1995. Interviewing applicants for refugee status: Training module. Geneva: Training Service Rapid Deployment Level 4.

Venuti, L. (ed.). 2000. The translation studies reader. London: Routledge.

Weber, M. 1947 [1915]. The theory of social and economic organization. New York: Free Press.

Woolard, K. 1999. Simultaneity and bivalency as strategies in bilingualism. Journal of Linguistic Anthropology 8(1). 3-29.

Youssouf, I., A. Grimshaw \& C. Bird. 1976. Greetings in the desert. American Ethnologist 3(4). 797-824.

Marco Jacquemet (B.A. Università di Bologna; M.A. EHESS, Paris; Ph.D. U.C. Berkeley) is Associate Professor and Chair of the Department of Communication, University of San Francisco. His current research seeks to assess the communicative mutations resulting from the intersection in the Mediterranean area between mobile people and media idioms. He published three monographs (Credibility in Court: Communicative Practices in the Camorra's Trials, Cambridge University Press 1996; Il Galateo del Cibernauta, Castelvecchi 1996; Ethereal Shadows: Communication and Power in Contemporary Italy, Autonomedia 2009) and multiple articles in edited volumes and refereed journals. Address for correspondence: Department of Communication Studies, University of San Francisco, 2130 Fulton Street, San Francisco, CA 94117, USA〈mjacquemet@usfca.edu〉. 
Copyright of Text \& Talk is the property of Walter de Gruyter GmbH \& $C_{0}$. KG. and its content may not be copied or emailed to multiple sites or posted to a listserv without the copyright holder's express written permission. However, users may print, download, or email articles for individual use. 